\title{
Design of the Pencak Silat Learning Model Using Variations in the Learning of Medan City Junior High School Students, North Sumatra Province
}

\author{
$1^{\text {st }}$ Rahma Dewi \\ Physical Education \\ State University Of Medan \\ Medan, Indonesia \\ rahmadewi368@gmail.com
}

\author{
$2^{\text {nd }}$ Novita \\ Physical Education \\ State University Of Medan \\ Medan, Indonesia \\ novita@gmail.com
}

\author{
$3^{\text {rd }}$ Fill Erwin \\ Physical Education \\ State University Of Medan \\ Medan, Indonesia \\ filerwin@gmail.com
}

\begin{abstract}
Asbtract - Basic motion learning is the main aspect that students must master. The pu rpose of this study was to determine the basic motion learning model of pu nches and kicks with games for junior high school students. To determine the feasibility of learning models of basic movements of strokes and kicks of pencak silat with games for junior high school students. This research method is a development model (R\&D), which is to produce a manual for the basic motion games of punches and kicks of pencak silat with games for jun ior high school students. The subjects of the product trial were junior hi gh school students, namely the small group trial of 30 people and 100 juni or high school students in the large group trial. The results of this stud y obtained the feasibility of learning the basic movements of pencak silat based on expert judgment and field trials obtained a percentage range of $84.28 \%-95.83 \%$. The conclusion of this research is that the learning model of the basic movements of pencak silat with games for junior high school students in Medan is declared "feasible" and can be "used".
\end{abstract}

Keywords - Variations, In The Learning, The Design.

\section{INTRODUCTION}

Physical Education is a medium to encourage the development of motor skills, physical abilities, knowledge, reasoning, value delusions (mental-mental-emotional-spiritualsocial attitudes), and habituation of healthy lifestyles that boil down to stimulating balanced growth and development, systematically planned in order to achieve national educational goals. The national education objective stipulated in Law 20 of 2003 on the National Education System, Article 3 [1], that "National education serves to develop the ability and shape the dignified dignified character and civilization of the nation in order to educate the life of the nation, aiming to develop the potential of students so that people who believe in god almighty, noble, healthy, knowledgeable, capable, creative, independent and become democratic and responsible citizens".

Learning at junior high school level needs to prioritize, modification forms in both the rules, the size of the field, and the number of players. If not modified, students are often unable and fail to carry out tasks given in the form of complex gestures by teachers. As a result of this condition, students can become less happy with the learning of physical education of sports and health. Teaching tasks that are complex skills can actually be performed in an effort to modify complex motion tasks into simple motion tasks. Therefore the need for sports modification in Penjas learning is absolutely necessary. Teachers in this case must have the ability to be able to modify the skills to be taught according to the level of development of the child.

Based on the conditions in the field the results of observations (interviews and answering questionnaires given to students and teachers) at one of the Junior High Schools in Medan. The results showed that pencak silat learning with conventional learning is less in demand and interesting so students and teachers want a game model with concentrated results ( $85 \%$ for students) and (75\% for teachers) of questions answered. This is because of the weight of the learning process, the boring learning atmosphere and other saturation, so that the innovation and creation of teachers is needed in developing various learning models so that the learning process does not become monotonous and boring. Students aged 13-14 or grades 7 and 8 junior high school should have great motivation in learning motion because according [2] at the age of 13-14 years is the most suitable age for the development of the skills basics needed in the future. There's no right or wrong term here.

Characteristics of junior high school students who love to play, love to move, enjoy working in groups and happy to feel or do things directly, make the right development model given the various basic motion learning pencak silat with games that of course the movement must support and relate to the basic movement of pencak silat. In this case the researchers limited the basic motion of the pecaxilate to be developed in the forms of the game namely the basic motion of hitting and kicking in the pencak silat.

In relation to the statements stated above, the researchers concluded that most of the students in junior high school do not like learning and training pencak silat. So it needs to be developed pencak silat learning with games that can later be used as a solution to facilitate students in learning basic movements pencak silat more effectively and efficiently.

Based on this explanation, this research aims to solve the needs of pencak silat learning model by using variations of learning for junior high school students in Medan, North Sumatra Province. There sfore, the problem with research is, 
"how can the learning model of pencak silat by using variations in learning can be used for junior high school students?

\section{METHODS}

\section{A. Research Method}

The design of the research conducted in this research is $\mathrm{r} \& \mathrm{~d}$ development research. [3] in The Research Method of Quantitative, Qualitative and R\&D Approach Education Research, measures of use of Research and Development (R\&D) methods modified the basic motion of pencak silat in junior high school with game methods approaches. Development research is a concept that aims to produce a new product or perfect an existing product that can later be accounted for. The development of learning models is a very systematic way of identifying, developing, and evaluating a set of materials and strategies geared towards achieving specific learning goals. [4]

Development research also applies organized knowledge to help solve problems in communities including the world of education. So development research is a process of how to develop something to be good and perfect. Maintaining the Integrity of the Specifications.

[5] Learning is a complex system whose success can be seen from two aspects, namely product aspects and process aspects. The success of learning in terms of product is the success of students regarding the results obtained by ignoring the learning process.

\section{B. Procedure of Research}

Once the potential and problems can be demonstrated factually, then it is necessary to collect various information that can be used as material for the planning of a particular product that is expected to solve certain problems. What methods will be used to research depending on the problem and the accuracy of the objectives that you want to achieve.

From the above potential and problems can be drawn the conclusion that there is a need for a basic motion learning process that corresponds to the characterization of junior high school children. This research will produce guidebooks and videos of basic motion learning pencak silat with games for junior high school students in Medan city.

\section{Technique of Data Collection}

Preliminary data collection techniques to obtain potential problems to be examined are drawn from library studies, journals, observations and interviews conducted to students and teachers, questionnaires, porto polio, documentation. Data from preliminary results collected will result in potential development research problems. The next step is for researchers to draft an initial product to solve potential problems.

\section{1) Product development process data}

Data on the process of preparation and development of basic motion games for junior high school students in the form of descriptive data, namely reviews and inputs from sports experts, sacred site ists and teachers in accordance with product development procedures

\section{2) Product data that is worth using as a medium}

Products that are worthy of use as a medium are determined through the analysis of the validation results of sports experts, sacred site ists, and teachers as well as the use of basic motion games in junior high school students to students in limited trials and usage trials. The results of the media use test in the form of quantitative data (score) are processed into qualitative data.

\section{Analysis Data}

Data analysis techniques in this research and development use descriptive analysis. All collected data is analyzed with descriptive statistical techniques quantitatively separated by category to sharpen the assessments that are then used to draw conclusions. Analysis of data is carried out on the reviews of experts as a result of expert judgement, in addition qualitative data in the form of inputs and suggestions is also grouped and analyzed whose results are used for product revision used in this case is the basic motion of pencak silat with the method of play.

Data analysis is an important step in research and development activities. So that it can review the results of the data that has been obtained before. The data analysis techniques used are tailored to the type of data collected. Some things to note in the data analysis include:

a. Data analysis includes data organization procedures, reduction, data presentation, with tables, charts, or graphs.

b. Data is classified by product type and component developed.

c. The data is analyzed as descriptive as well as in the form of quantitative calculations.

d. The presentation of data analysis results is limited to factual, without developer interpretation, so as a basic assumption in revising the model

e. In the analysis of data usage calculations and statistical analysis in line with the problems raised.

In the research and development of this data analysis technique used is a quantitative descriptive analysis technique with percentage. This technique is used to analyze quantitative data obtained from the observation of the learning process of pencak silat. The formula used to analyze the data is as follows:

\section{FINDING AND DISCUSSION}

\section{A. Initial data for basic motion game model needs}

The results of observations to collect preliminary data for the needs of basic motion game models based on learning pencak silat (sacred sites) with conventional learning are less desirable and interesting so students and teachers want a game model with the results of censoring ( $85 \%$ for students) and ( $75 \%$ for teachers) from the questions answered. This is because of the weight of the learning process, the boring learning atmosphere and other saturation, so that the innovation 
and creation of teachers is needed in developing various learning models so that the learning process does not become monotonous and boring.

\section{B. Product Validation}

Product validation in pencak silat basic motion game is validated by several experts including:

Table 1. The initial and final product validation results in pencak silat basic motion game are validated by several experts including:

\begin{tabular}{|c|c|c|c|}
\hline No & Assessment Stage & $\begin{array}{r}\text { Average } \\
\text { Aspects }\end{array}$ & Presentase \\
\hline \multicolumn{4}{|c|}{ Early Product Validation By Experts } \\
\hline \multicolumn{4}{|c|}{ Product Validation Results (Sports Experts) } \\
\hline 1 & Preparation & 3,75 & $75 \%$ \\
\hline 2 & $\begin{array}{l}\text { Game Product } \\
\text { Creation }\end{array}$ & 4 & $80 \%$ \\
\hline 3 & Product assessment & 3,25 & $65 \%$ \\
\hline \multicolumn{4}{|c|}{ Product Validation Results (Trainer) } \\
\hline 1 & Preparation & 4,25 & $85 \%$ \\
\hline 2 & $\begin{array}{l}\text { Game Product } \\
\text { Creation }\end{array}$ & 4,16 & $83,33 \%$ \\
\hline 3 & Product assessment & 4,25 & $85 \%$ \\
\hline \multicolumn{4}{|c|}{ Product Validation Results (Language) } \\
\hline 1 & Preparation & 3,5 & $70 \%$ \\
\hline 2 & $\begin{array}{l}\text { Game Product } \\
\text { Creation }\end{array}$ & 4 & $80 \%$ \\
\hline 3 & Product assessment & 3,75 & $75 \%$ \\
\hline \multicolumn{4}{|c|}{ Final Product Validation } \\
\hline \multicolumn{4}{|c|}{ Product Validation Results (Sports Experts) } \\
\hline 1 & Preparation & 4 & $80 \%$ \\
\hline 2 & $\begin{array}{l}\text { Game Product } \\
\text { Creation }\end{array}$ & 4,16 & $83,33 \%$ \\
\hline 3 & Product assessment & 4,5 & $90 \%$ \\
\hline \multicolumn{4}{|c|}{ Product Validation Results (Trainer) } \\
\hline 1 & Preparation & 4,75 & $95 \%$ \\
\hline 2 & $\begin{array}{l}\text { Game Product } \\
\text { Creation }\end{array}$ & 4,83 & $96,6 \%$ \\
\hline 3 & Product assessment & 4,5 & $90 \%$ \\
\hline \multicolumn{4}{|c|}{ Product Validation Results (Language) } \\
\hline 1 & Preparation & 4,25 & $85 \%$ \\
\hline 2 & $\begin{array}{l}\text { Game Product } \\
\text { Creation }\end{array}$ & 4,3 & $86,6 \%$ \\
\hline 3 & Product assessment & 4,25 & $85 \%$ \\
\hline
\end{tabular}

\section{Small group trials and large group trials}

Small-scale trials were applied to junior high schools with trial subjects of 30 junior high school students. The results of the trial of pencak silat basic motion game products were obtained by the test subjects with an average range of 3.163.54 answers and a percentage range of $79.81 \%-88.54 \%$.

Large-scale trials were applied to SMP Muhammadiyah Tanjung sari with a trial subject of 100 junior high school students. The results of the trial of pencak silat basic motion game products were obtained by the test subjects with an average range of 3.41-3.83 answers and a percentage range of $85.41 \%-95.83 \%$.

\section{Discussion of the results of the study}

Based on the discussion of the results of the research of the basic motion learning model with the game goes through the procedure of developing and validation of competent experts in their respective fields. Based on expert validation results and field trials obtained a percentage range of basic motion learning product assessments of $84.28 \%-95.83 \%$. That percentage is an excellent category on the results of assessment of basic motion learning products with the game. Therefore, from the results of the study can be concluded that the basic motion learning model of pencak silat with the game is categorized as feasible and can be used as a reference material for learning pencak silat in junior high school in Medan City.

In this study, i.e. developing basic motion games on martial arts pencak silat sacred site. [6] In general, there are 9 basic aspects of pencak silat technique that should be understood by anyone who wants to pursue martial arts pencak silat this sacred site.

Play is some of the main activities that begin to be seen since the baby is 3 or 4 months old, important for the cognitive, social and personality development of the child in general. [7].

[8] said that the game has two understandings. First, the game is a purely fun-seeking activity without looking for a win or lose.

\section{CONCLUSION}

Based on the data obtained, from small group trials and field trials and discussion of the results of the study, it can be concluded that the feasibility of the basic motion learning model of pencak silat with games for junior high school students in the terrain city is declared "feasible" and can be "used". Authors and Affiliations

\section{REFERENCES}

[1] Undang-Undang republik Indonesia Nomor 20 Tentang sistem pendidikan nasional. 2003. Jakarta: Sekretariat Negara 
[2] Syarifuddin, Aib dan Nurhadi. 1992. Pendidikan Jasmani dan Kesehatan. Jakarta: Depdikbud. Dirjendikti. Proyek Pembinaan Tenaga Kependidikan

[3] Sugiyono. 2008. Metode Penelitian Kuantitatif, Kualitatif dan R \& D Bandung: Alfabeta

[4] Istarani. 2012. Kumpulan 40 Metode Pembelajaran Untuk Revolusi Mengajar. Medan: Media Persada
[5] Sanjaya, Wina. 2011. Pembelajaran dan Implementasi. Jakarta: Kencana.

[6] Johansyah, Lubis dan Hendro Wardoyo. 2014. Pencak Silat. Jakarta: Raja Wali Sport

[7] Tedjasaputra, Mayke s. 2001. Bermain, Mainan dam Permainan Untuk Pendidikan Anak Usia Dini. Jakarta: Grasindo

[8] Sadiman, Arif S. 2003. Media Pendidikan Pengertian, Pengembangan dan Pemanfaatanya. Jakarta: Pustekum Dikbud 